\title{
Advice and dissent in White House science
}

\author{
Harvey Brooks
}

THE growing literature of science policy generally includes two kinds of books: first-hand accounts of their own experience by principal actors in the processes of highlevel scientific decision-making, such as those by James Killian, George B. Kistiakowsky and Herbert York; or analytical discussions by academic scholars based on study of official documents or interviews with the principal actors. Edward Burger attempts to build a bridge between these two genres. A member of the staff of the Office of Science and Technology (OST) from the time of the first Nixon administration to the abolition of the President's Science Advisory Committee (PSAC) and OST in 1973, Dr Burger has built his book firmly on his own first-hand experience as an insider, but at the same time has attempted to bring a historical and analytical perspective to this experience and to put forth some important generalizations.

To the average observer of science policy, the Nixon administration tends to be viewed as the low point in the history of science in the White House. The rather sudden decision to abolish the presidential science advisory apparatus in January 1973 overshadows the many constructive initiatives that arose during this period. As Burger reminds us, this was a time when the effort to "civilianize" OST and PSAC to bring scientific considerations and the potential of science fully to bear on some of the nation's major sociopolitical issues such as health care, environmental regulation, population policy and urban policy - reached its climax.

His account is notable for its political sophistication and sensitivity to the multiplicity of influences bearing on even the apparently scientific decisions. It is also refreshingly free of self-justification or overstatement of the role of science. The chapters on national health policy, on environment and health, and regulation to protect health and on population and family planning contain a wealth of new material relating to major Nixon administration initiatives in social policy which gradually became diluted by pluralistic political pressures. These chapters are well worth reading even by those who care little about science policy or the role of science in the White House.

The subtitle of the book is unfortunately somewhat ambiguous and fails to do justice to all the themes which Burger develops. Its meaning is never fully explained and conveys implications that are not really supported by Burger's detailed conclusions. It is thus not clear whether he means to imply that having a Science Advisor in the White House is a
Science at the White House: A Political Liability. By Edward J. Burger Jr. Pp. 208. ISBN 0-8018-2433-8. (Johns Hopkins University Press: 1980.) \$14.95, $\$ 9$.

political liability to the President, which tends to tie his hands in negotiating with the many contending constituencies that he has to satisfy, or whether having a prominent presence in the White House is a political liability for the scientific community which compromises its long-term credibility before the public. Perhaps both statements are true, but I do not believe that the implication that science should be taken out of the White House is either intended by Burger or justified by the case histories which he analyses so perceptively.

In fact one could argue that science in the White House enjoyed some of its finest hours during the period covered by this account, if retaining the intellectual honesty of science in the policy process is used as a criterion. The report on Chemicals and Health, published by the National Science Foundation after the demise of PSAC, is still one of the most thorough and balanced discussions of this controversial topic. Issued in a climate of overwhelming environmental activism, its sober and balanced approach was little appreciated or heeded until much later. Had it been heeded, some of the current over-reaction against the earlier excesses of the environmental movement might have been avoided. The Toxic Substances Control Act (1976) derived from a concept that originated from the staff of the Science Advisor. The OST staff, and Burger in particular, played a central role in shaping the recommendations of the Health Policy Review Group (1971) and the subsequent Presidential Message on Health. The analysis of the Review Group stands up very well today, though it had little political effect at the time. The OST also played an important role in following up the report of the Population Commission (1972), although here again the analysis was ahead of its time in political terms. The Science Advisor played a reluctant but sensible role in devising the Quality of Life Review Process for considering the social and economic impacts of regulatory decisions, anticipating the regulatory review process established in the Carter administration. The Science Advisor chaired a special committee created by the President to study the rather grandiose and politically motivated proposal for a New Technology Opportunity Program in 1971.

The recitation of these examples, however, poses the dilemma suggested in the title of the book. In referring to these activities favourably I am making an intellectual - not a political - judgement, because in most instances the input from the OST, as Burger suggests, must be rated a political failure. The intellectual conclusions were mostly out of tune with the political climate and the President's political goals - the classic problem of "speaking truth to power"'. The report on Chemicals and Health took too long to complete and appeared too late to have any significant impact on policy, and its balanced approach was out of tune with the public's mood. By the time the hard hitting and clever recommendations of the Health Policy Review Group had been distilled into a presidential message, much of the bite had disappeared, and health as a salient political issue had faded into the background. Much the same fate befell the report of the Population Commission. The task force to follow up the report completed its work at a time when political concern over US population growth had faded with the dramatic decline in fertility in the early 1970 s. Although the task force called for a presidential statement to endorse the Commission's principal recommendation for a national population stabilization policy, the chairman privately sabotaged this recommendation. The technology initiatives programme, which was launched with great political fanfare, quietly foundered when $\mathrm{Dr}$ Edward David's standing committee discovered there was much less there than met the eye, and was unable to identify any dramatic government initiatives that stood up to scientific scrutiny.

We thus end with a picture in which strong recommendations based on scientific input failed politically because they ran counter to the prevailing climate or antagonized strong political interests, on the one hand, or in which careful analysis debunked political initiatives on which the President had set great store, on the other. Are the Science Advisor and his staff to be praised for "speaking the truth to power", for calling the shots as they saw them and for thoughtful and forward-looking policy analysis. Or are they to be criticized for insufficient awareness of political realities and of the sensitivities of important political constituencies to which the President must respond? Is the performance of science in the Nixon White House to be viewed as a series of honourable failures derived from commendable devotion to intellectual honesty and objectivity? Or is it to be condemned as the mark of politically naive amateurs incapable of appreciating and responding to the legitimate political needs of the chief executive? Burger poses these 

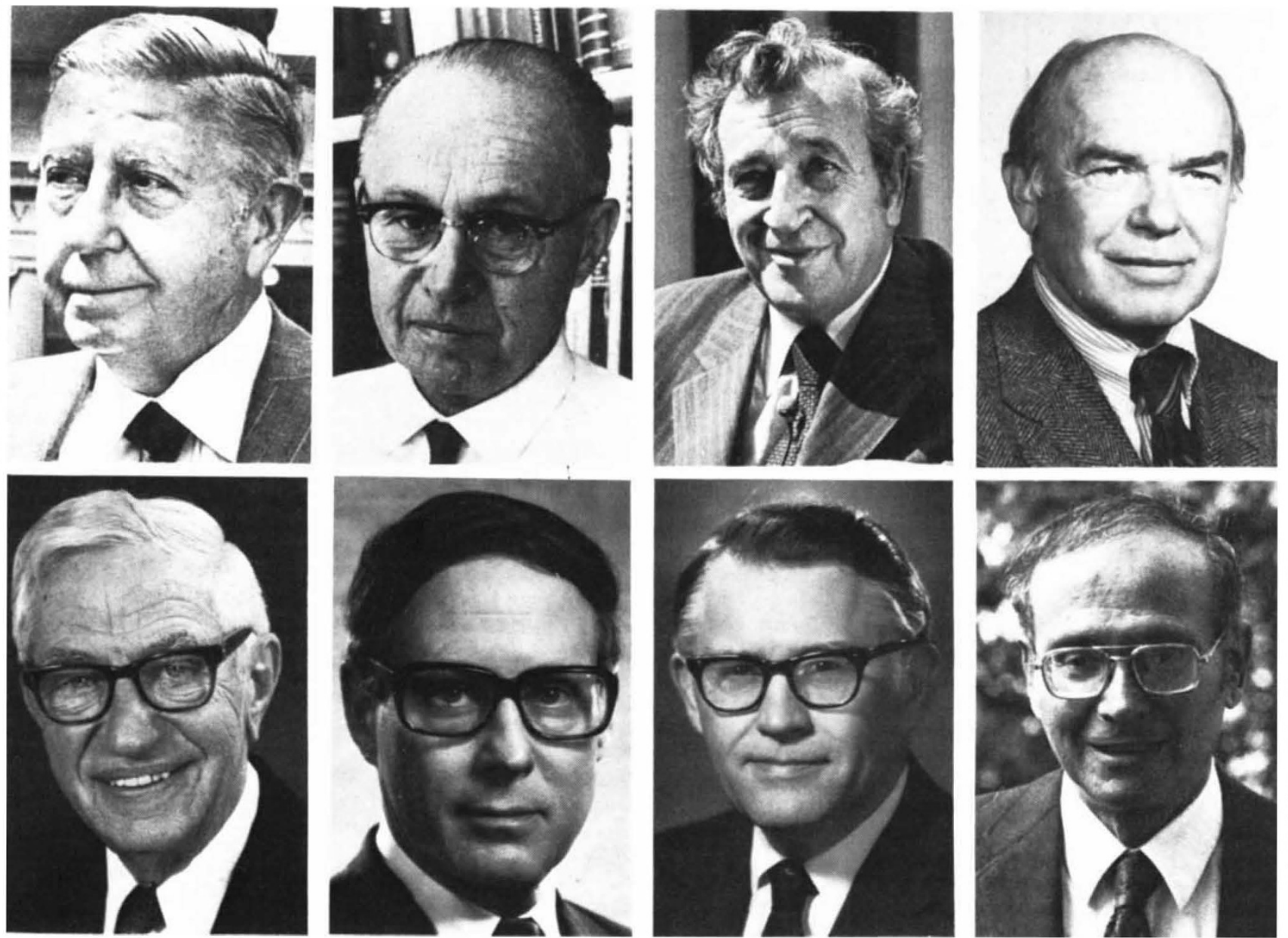

Scientists at the White House, 1957-1981. Left to right, top to bottom: James Killian Jr (served under Truman, 1957-1959); George Kistiakowsky (Eisenhower, 1959-1961); Jerome Wiesner (Kennedy, 1961-1964); Donald Hornig (Johnson, 1964-1969); Lee Du Bridge (Nixon, 1969-1970); Edward David Jr (Nixon, 1970 to 1973 when PSAC and OST were abolished); H. Guyford Stever (Ford, 1976-1977);

Frank Press (Carter, 1977-1981). President Reagan has not yet appointed a successor to Press.

questions cogently in each of the examples which he analyses, but he does not really give us the answer. Perhaps there is no single answer and the greatest contribution of the book is revealing the dilemma in realistic detail.

An important theme of this book, set forth in Chapter 2, is the fundamental conflict between rational policy planning and the push and pull of pluralistic political interests. The author presents the executive branch and the scientists as the proponents of such rationality against the pluralism embodied in the legislature. Yet there is a paradox here, which is not fully resolved in the book. It is true that in the efforts to introduce Program Policy Budgeting (PPB), to develop a comprehensive health policy or to formulate a rational and balanced national policy for environmental regulation, Burger's model seems to apply. But he fails to note that in policy for science, as contrasted with science for policy, the roles of the scientists and politicians appear to be reversed. It is Congress that has continually pushed for a comprehensive national policy for science, most notably in the National Science and Technology Policy, Organization and Priorities Act of 1976. Furthermore, this is not a new phenomenon. In the nineteenth century, Congress was the repeated source of proposals for a cabinet Department of Science. In every case it has been the scientific community and the executive branch that have dragged their feet in regard to the comprehensive planning of science and technology. More recently, OSTP under the Carter administration has attempted to divest itself of most of the planning and systematic reporting functions mandated by the 1976 Act. Whereas Congress has viewed OSTP and the Science Advisor as a kind of general staff for science and technology in the United States, the Science Advisor and most of his constituency in the technical community have viewed his role more modestly and have strongly favoured a pluralistic, decentralized approach to the support of science itself.

It is interesting to speculate on the causes of this paradox of science as the advocate of planning in the spheres of public policy and pluralism in the field of science, while the Congress and the more politically minded Executive take the exactly opposite view. The answer may lie in the internal politics of the scientific community itself. This community is not a monolithic group but rather congeries of frequently conflicting interests and views. Planning for science, especially by scientists, entails a high political cost within the scientific community, which would rather take its chances on the free play of political advocacy between the different segments of the scientific community and the political process. It would have been desirable if Dr Burger had explained this particular paradox a little further.

Altogether, though, this is a valuable book which should be of interest to a wide public. It provides some fascinating insights into some of the major social policy debates of the early 1970s; it is a contribution to the analysis of the role of White'House science advice from the perspective of a staff officer carrying out policy support rather than making policy; and it provides excellent case material for scholars and students in the field of science policy. On top of that it is well written, literate and sophisticated.

Harvey Brooks is Benjamin Pierce Professor of Technology and Public Policy at Harvard University. He was a member of the President's Science Advisory Committee from 1959 to 1964. 